Acta Horticulturae et Regiotecturae 2

Nitra, Slovaca Universitas Agriculturae Nitriae, 2020, pp. 101-107

\title{
IMPROVING COMMUNITY HEALTH AND WELLBEING THROUGH MULTI-FUNCTIONAL GREEN INFRASTRUCTURE IN CITIES UNDERGOING DENSIFICATION
}

\author{
Bruno MARQUES*, Jacqueline McINTOSH, Victoria CHANSE \\ Victoria University of Wellington, Wellington, New Zealand
}

\begin{abstract}
Evidence shows that maintaining a relationship with nature is essential for human health and wellbeing. This is of great importance when migration to urban areas is increasing globally and the need for nature as well as green and blue spaces as a source of recreation and relaxation is highly regarded for the health and wellbeing of local communities. Sustainable urban development and alternative design solutions to address urban compactness and densification are becoming increasingly important tools to counteract the adverse effects of urban sprawl. In the context of the highly compact bicultural capital city of Wellington, Aotearoa-New Zealand, this paper examines the effects of urban densification and compact city development in urban green spaces. It explores how architecture and landscape architecture can transform urban environments into desirable places to live and capitalise on the potentials of interstitial spaces, outdated zoning and changing land-use. To achieve that, it looks at green and blue infrastructure design solutions and opportunities that foster sustainable intensification and by offering new views for health and wellbeing that improve the social, cultural and environmental health of the city.
\end{abstract}

Keywords: green and blue infrastructure, compact cities, culture, health and wellbeing

With the number of urban dwellers expected to rise from 54 to $69 \%$ by 2050, or 6.3 billion people (United Nations, 2018), the pressure in urban areas and populations is increasingly critical. Individual and community ill-health and loss of wellbeing of city residents is escalating with rapid urbanisation. Forecast increases in urban population are similar both globally and locally in Wellington, AotearoaNew Zealand. The next 30 years will see a $10-15 \%$ increase (United Nations, 2018) in people living in cities around the world and in Wellington, the city's population is projected to increase by approximately $20-36 \%$ over the next thirty years (Wellington City Council, 2020).

As places become more urbanised, the compact urban forms compete with green space. Urban green spaces are generally characterised by small, isolated, or unevenly distributed lots, appearing in different shapes and sizes. Intensification associated with urbanisation destroys natural landscapes and devastates rich indigenous ecologies (Kamiryo, Sakashita and Matsumoto, 2011). The juxtaposition of housing and related built infrastructure with minimal interstitial space can also pose a significant threat to biodiversity and human health.

In the face of rapid densification in urban areas, the need for multi-functional green spaces, and the associated services derived from them, is critical. These green spaces play a vital role in supporting the human-nature interaction (Kim and Coseo, 2018; Kim and Miller, 2019; Kim, Miller and Nowak, 2015), urban sustainability, environmental quality and human health and wellbeing (Kaplan, Kaplan and Ryan, 1998). Research demonstrates a positive relationship between access to nature and natural processes and human health and wellbeing (Hartig et al., 2014; Kuo, 2015; Seligman, 2002) as well as the role of nature in restoring cognitive processes in people (Kaplan and Rogers, 2003; Kaplan, Kaplan and Ryan, 1998). Biophysical attributes such as water and greenery are seen as highly restorative to our health and wellbeing and contribute to how we experience a place (Kuo, Bacaicoa and Sullivan, 1998). A strong sense of place increases place attachment and develops a stronger sense of use and care, contributing to an enhanced sense of community (Marques, Mclntosh and Campays, 2018). Similarly, many studies report comparable results on the positive effects that blue spaces, such as rivers, lakes or the sea, have in the health and wellbeing of individuals both through views and sounds of water (De Vries et al., 2016; Grellier et al., 2017; Nutsford et al., 2016; Voelker and Kistemann, 2013; Wheeler et al., 2012).

However, Green Infrastructure (GI) is more than just 'greening' urban environments via creating open spaces and green corridors. Implementation of green infrastructure in urban environments provides significant social and cultural benefits by bringing together people and nature (Buizer et al., 2016). Cultural regeneration is generally associated with green infrastructure as it connects places with people through creating nurturing cities, vital custodianship and wellbeing (Menzies, Renata and Whaanga-Schollum, 2016). Healthy ecosystems hereby have the capacity to provide a comprehensive range of services (Costanza et al., 1998; Lu and Li, 2003). 
In the context of compact cities, Gl is a critical framework for designers and planners to identify underutilised interstitial spaces as opportunities to provide amenities to individuals and communities (Chanse et al., 2017; Nikologianni, Moore and Larkham, 2019). Compared with many countries internationally, Aotearoa-New Zealand is not the first to come to mind when thinking about compact cities. However, due to the rugged and steep topography, the geography of Wellington had led to a highly compact urban form (Marques et al., 2019). The city is characterised by an amphitheatre of hills that lead to the waterfront. The city's urban form has also developed by broader policies of containment and compact suburban development.

The aim of this paper is to discuss opportunities and potential consequences of the green and blue infrastructure approach in the context of the compact city with particular focus on the socio-cultural dimensions of the human-nature interaction. This paper draws from design research projects in Wellington, Aotearoa-New Zealand to examine the role of green infrastructure as a design strategy and a framework to improve community health and wellbeing in urban areas. Gl provides an array of solutions that bring together natural and semi-natural areas and elements in rural and urban areas, while providing a wide range of ecosystem services and functions to cope with unforeseen challenges (Barthel et al. 2015; Elmqvist et al. 2013; Folke, 2006; Gallopín, 2006; Kim and Miller, 2019; Tóth, Halajová and Halaj, 2015; Vierikko et al., 2016). The concept of Gl comprises both the quantity and the quality of urban, suburban and rural green spaces (Rudlin and Falk, 2009; Tzoulas et al. 2007), their multifaceted roles (Sandström, 2002) and the interconnectedness of habitats (Van der Ryn and Cowan, 2013). A carefully planned $\mathrm{Gl}$ has the potential to boost urban development as it provides a coherent framework for economic growth, nature conservation and public health promotion (Schrijnen, 2000; Walmsley, 2006).

\section{Material and method}

This paper examines two green infrastructure propositions which adopted a 'research through design' methodology, where both context and phenomenon were investigated conjointly through the positioning of theory with case studies (Lehman and Nelson, 2014). The two contrasting studies, one dealing with horizontal space in Kent and Cambridge Terrace and the other engaging with vertical green space near Waiteata Road, are both situated in the compact capital city of Wellington, Aotearoa-New Zealand, and explore the human-nature relationship as well as the socio-cultural regenerative forces within green-blue infrastructure. One study addressed the importance of green and blue infrastructure in relation to ecosystem services, while the other looks at the importance of green infrastructure in relation to human mental health and wellbeing.

\section{Case Studies}

In both studies, following literature review and case study analysis, key themes were identified as design performance

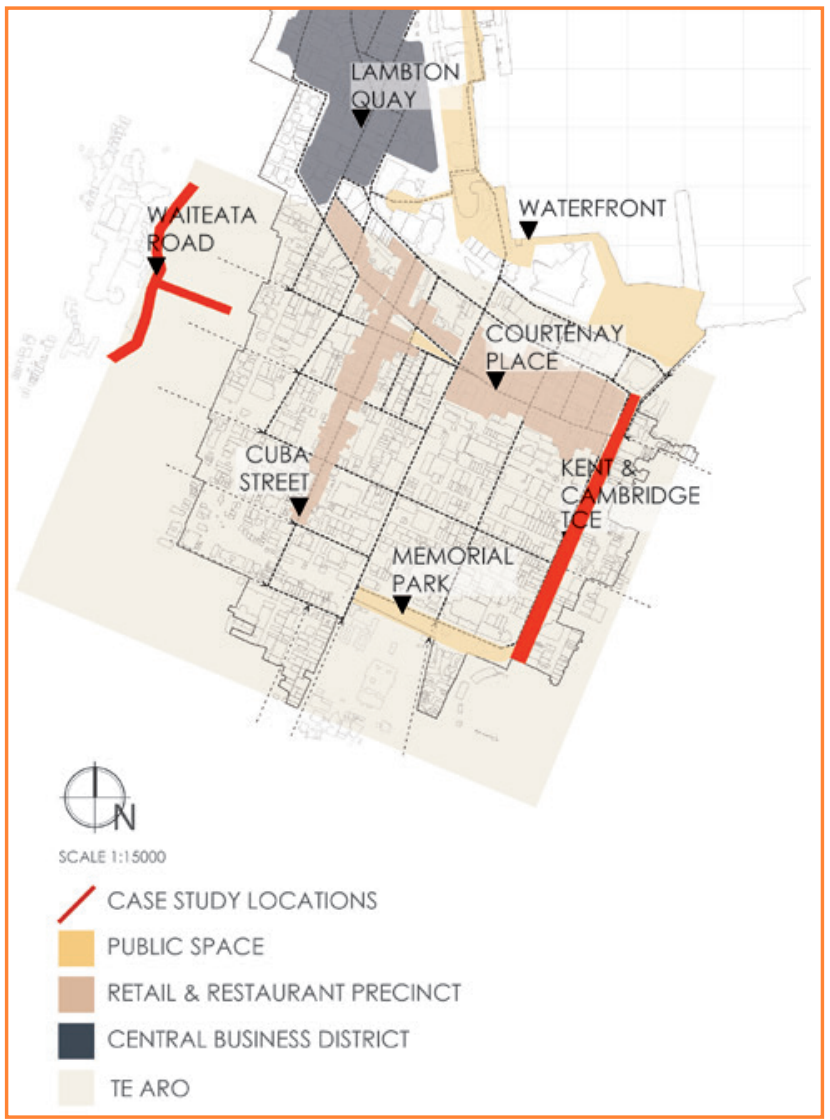

Figure 1 Map of Te Aro downtown suburb in Wellington, showing the location of Kent and Cambridge Terrace (case study 1) and Waiteata Road (case study 2)

criteria for improving community health and wellbeing in urban areas. The extracted super-ordinate themes were: green and blue infrastructure, ecosystem services, and human health and wellbeing.

Wellington has been defined as a compact city due to its containment by steep topography and extensive waterfront, despite its relatively low population compared with the highly urbanised compact cities internationally. Both case studies are located in the extreme ends of the central downtown suburb of Te Aro: Kent and Cambridge Terrace and Waiteata Road (Figure 1). With the increased densification of the inner city, and the subsequent increased transportation through the centre, both the existing and the potential for new or improved green infrastructure are placed in jeopardy.

Te Aro takes up the majority of Wellington's central urban area. It is filled with busy cafes, bars, restaurants, commercial and some light industrial uses as well as high and medium density housing and a few remnants of low-density housing. It has a young and dynamic demographic as it supports a large percentage of students and young professionals due to its proximity to two universities, governmental agencies and a large creative sector. As urban growth puts pressure on the inner city green space and while resources are limited, opportunities arise for landscape architecture to provide innovative nature-based solutions to balance the stress-inducing noise and growing sea of concrete and asphalt. 


\section{Green and blue infrastructure and the importance of ecosystem services: the case of Kent and Cambridge Terrace}

The first case-study is situated between Cambridge and Kent Terrace, two large north-south arterial roads that run parallel to the edge of the city zone area, connecting the southern suburbs to Wellington City. These roads provide the main state highway connection to the international airport and as such are essential transport routes which have developed into fast-moving transport corridors. Increasingly, they create a substantive pedestrian barrier which has divided neighbourhoods and hindered a peoplecentric development of this area.

Beneath this busy urban corridor runs Waitangi Stream, which begins in Mt Cook, travels north under the Basin Reserve and finishes at Waitangi Park. Urbanisation pressures have resulted in the culverting of Waitangi Stream 5 meters below Kent and Cambridge Terrace where it collects the stormwater for the adjacent suburbs of Mount Victoria and Mount Cook as well as part of Te Aro. This stream corridor is the key to flood management and the harbour water quality in Te Aro. Yet, it has been disregarded and replaced by roading infrastructure like many other urban streams.

Much research has reported on the link between green and blue infrastructure, ecosystems health and ecosystem services (De Vries et al., 2016; Elmqvist et al., 2013; Grellier et al., 2017; Pedersen Zari and Hecht, 2020; Rapport, Costanza and McMichael, 1998). Research finds that opportunity lies in re-instating habitats and species that benefit urban biodiversity as well as contributing to human wellbeing (Tilman, Isbell and Cowles, 2014). Researchers also note the close and beneficial relationship between ecosystem health and ecosystem services, for delivering, providing, protecting and maintaining goods and benefits that derive from nature for the betterment of humans (Bolund and Hunhammar, 1999; De Groot, Wilson and Boumans, 2002). Therefore, spaces that are designed and adopt Green and Blue Infrastructure solutions can contribute to ecosystem health and public health, respectively.

The proposed approach to this site looks at the importance of green infrastructure as providing ecosystem services that enable the re-activation of urban areas, and also at the social dimensions of space as a way to reconnect communities with nature. From an analysis of the existing pedestrian and public space structure of neighbourhood and the barriers to pedestrian flow, the research re-forges the broken link down the Kent and Cambridge corridor in a way that facilitates pedestrian thoroughfare, increases public space and restores natural systems. It achieves this through raised pedestrian corridors, daylighting the stream corridor to both address urban drainage and flood management and local ecologies as well as provide a much needed new urban space for recreation and leisure. In this way, green infrastructure

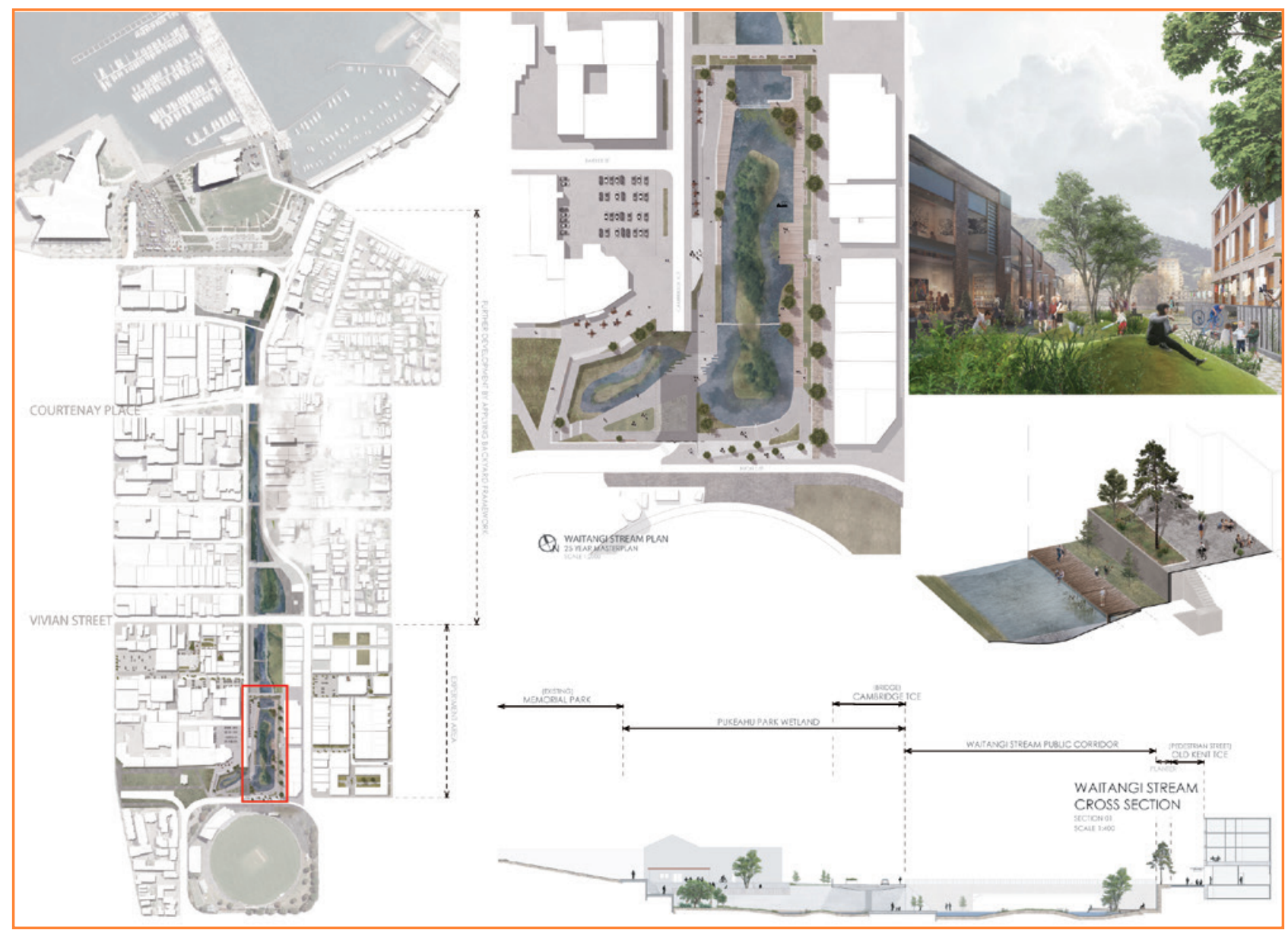

Figure 2 Design-led research exploration for Kent and Cambridge Terrace: masterplan, section, axonometric detail, and render 
supports the physical, mental, emotional and socioeconomic benefit to individuals and the community offering substantially increased amenity.

In this first case study, the design (Figure 2) explores opportunities for reclaiming nature for people while strengthening and renewing the natural systems. The design includes many essential ecosystem functions and services that tap into the biological, physical, aesthetic, recreational and cultural spheres of this innercity suburb. In doing so, it also reduces the dependence on purely grey infrastructure solutions, which tend to be more expensive and less sustainable if compared to nature-based solutions. In this case study, the green infrastructure solutions adopted offer an alternative to obsolete built stormwater infrastructures by lowering the costs of stormwater management as well as reducing the heat island effect, while maintaining protection from floods and drought. But perhaps most importantly, it reunites the suburb, providing a thoroughfare to enhance social interaction and a psychological and cultural refuge for users as they engage with the restored ecosystems and nature.

\section{Green infrastructure and human health and wellbeing: the case of Waiteata Road}

The second case study is situated on one of the steep hillsides that contain and densify the city core. Here the rugged topography defines the layout of the extensive urban road and infrastructure network. This proposition is located on the south-west face, strategically situated between Victoria University of Wellington's main campus and the Central Business District (CBD). In this case, vertical topography creates a movement barrier rather than a horizontal arterial roadway. The design explores how architecture can play an essential role in transforming a neglected hillside to an environment conducive to pedestrian flow and improve health and wellbeing.

Rather than creating a hard connecting infrastructure of asphalt switchbacks down the hillside, this research proposition employs a central pedestrian spine which supports a variety of multi-sensorial options and student-driven spaces, fostering social encounters and opportunities for quiet reflection. The proposed architectural scheme has a minimal impact on the natural setting. It emulates its surroundings through the augmentation of the existing ecological network as a means of alleviating the ecological impacts of habitat fragmentation. The scheme follows an environmental practice that suggests that an interconnected network of natural areas and open spaces as well as technologies and practices that use natural systems or engineered systems. Such approach mimics natural processes to enhance environmental qualities that can conserve ecosystem functions and natural capital, sustain clean air and water, and provide social and economic benefits to people and communities (Allen III, 2012).

The research through design approach requires the development of ideas, followed by critical reflection and testing to ensure that they meet with performance criteria. In this case study, the initial ideas (Figure 3) proved visually exciting to a design review panel of international scholars and practitioners; however, on reflection the design failed to

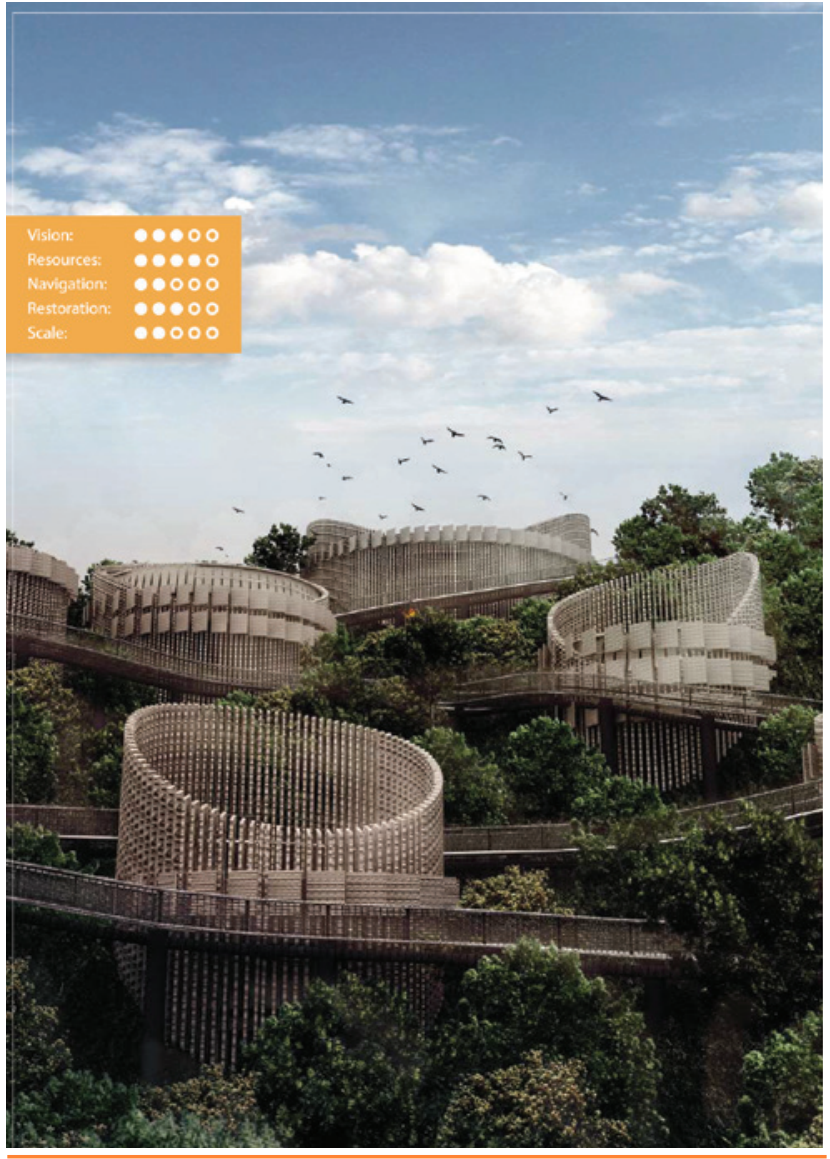

Figure 3 Early design iteration

sufficiently meet objectives for vision, navigation and scale. Further iterations developed the main ideas further leading to a final developed design that achieved all of the goals of the research.

This scheme acknowledges the stress of university students and the high rates of poor mental health as it seeks to slow the progression from town and possible residence to classroom and vice versa. The creation of pause moments, adjacent health-related facilities and lookouts all contained in an immersive green infrastructure can aid in both feelings of wellbeing, but also improve mental health. The use of green infrastructure in architecture can hereby offer a forward-thinking alternative to mainstream ideas improving life in different ways through its environmental, social and economic dimensions (Fig. 4). Looking at the architectural object as part of the green infrastructure allows to maintain the integrity of habitat systems and may provide the physical basis for ecological networks while contributing to benefit the user from the connection to nature (Tzoulas et al., 2007). This integrated approach between architecture and landscape architecture offers many opportunities for connection between urban development, nature conservation and public health promotion. Ecological and working landscapes are linked to human communities acknowledging that they are inextricability linked and that healthy landscapes are essential to human health, vitality and quality of life (Allen III, 2012). 


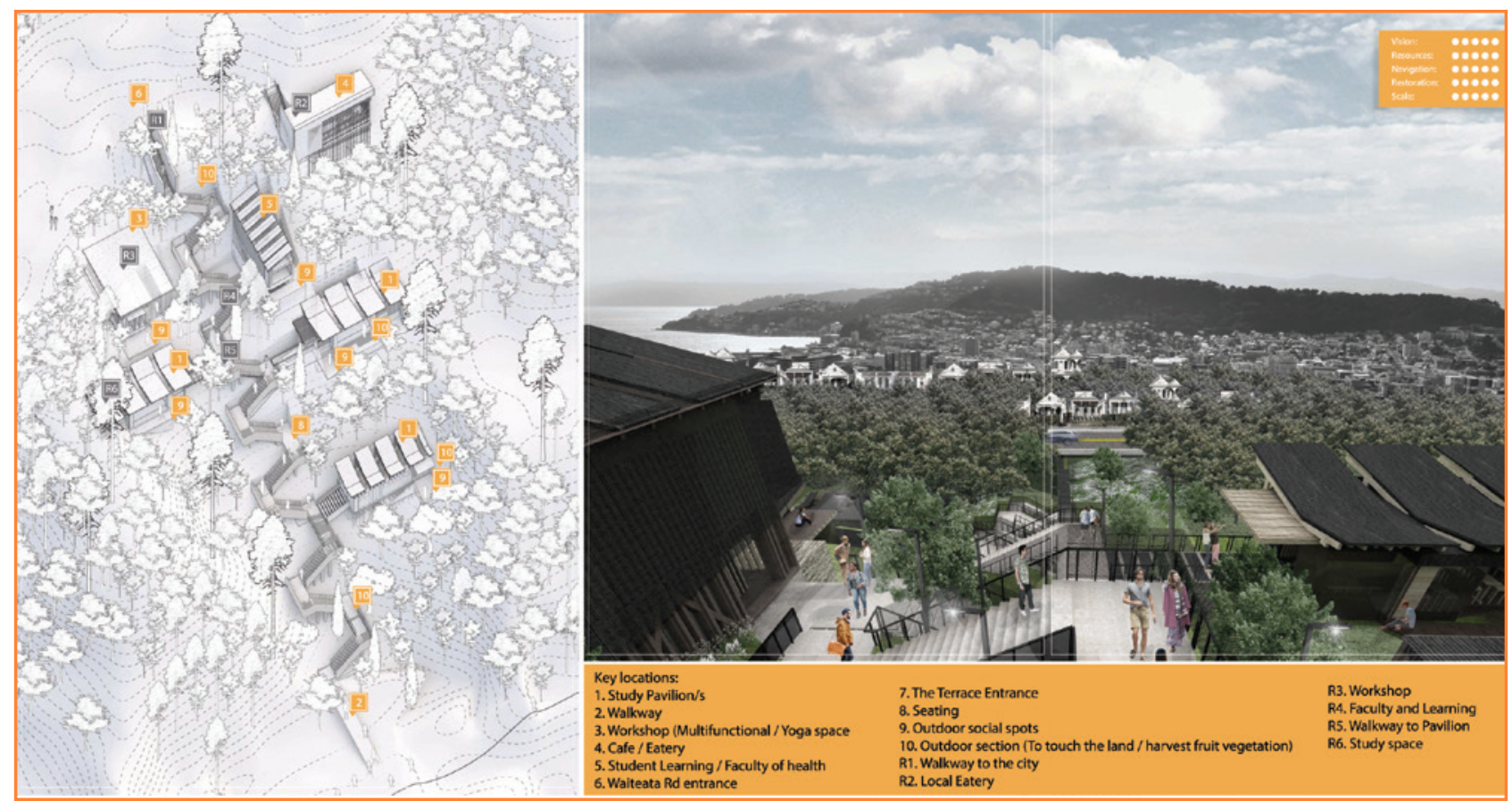

Figure 4 Final design proposal for Waiteata Road and view towards Wellington downtown

\section{Results and discussion}

This research examines two design-led research projects in the Wellington downtown suburb of Te Aro. Comparing and contrasting a horizontal landscape architecture exploration with a vertical architectural proposition, including landscape architectural elements, it shows two ways that innovative $\mathrm{Gl}$ can be reinserted into a compact city. Both case studies looked at interventions that adopt blue and green infrastructure solutions to create a more permeable suburb. These studies contribute to the discourse on the compact city and the increased importance of Gl for human health and wellbeing. Such interventions can also help to rebuild and strengthen communities by offering more opportunities for social interaction, 'community' projects and gatherings.

Through the juxtaposition of public and private spaces, green-orientated 'focal points' such as those in the case studies, can also foster a stronger sense of community and give individuals a place to relax, reflect, meet and play. As such they become extensions of our own private living premises when we choose to appropriate them, and in other times they are simply a thoroughfare. This flexibility provides users with the opportunity to define their spatial boundaries and actively engage with the urban ecosystem at large, with choice. Therefore, it makes sense that these 'focal points', the places in which we gather and engage in activity with others, should help to support our fondness for landscape. As the community strengthens, more social activities will occur and subsequently allow for people to manifest in these spaces.

The properties of an ecosystem can be seen as complex, open, ordered and self-organising. As a system, the different parts work together to produce emerging properties, where all components interact directly or indirectly, within defined boundaries (Lovett et al., 2005). The scale of such systems is highly dependent on their function. However, a holistic understanding is necessary (Menzies, Renata and Whaanga-Schollum, 2016). In the context of Aotearoa-New Zealand, our understanding must acknowledge the social and cultural uniqueness of place and connect with our assumptions and our deeper beliefs, values and behaviours (Collins, 2005; Hampden-Turner and Trompenaars, 2011).

Belief systems are a set of values resulting from collective and cumulative experience. Nature has cultural, social, health and spiritual meaning to many people, especially for New Zealand Māori (Clarkson and Kirby, 2016). In AotearoaNew Zealand, our bicultural stance opens new opportunities for a deeper appreciation of the role of nature in the urban setting. For Māori, the Indigenous people of New Zealand, humans and nature are part of an intertwined ecosystem seen as a cycle and an energy. From this energy comes the production, consumption and decomposition of landscape as part of a cycle. In this way, the breadth of qualities beyond the visual are key to an urban restoration that tries to reconnect people with nature. In both case studies, such approach to urban restoration aimed to enhance habitats, reconnect spaces with the integration of blue and green corridors, and extend green space to incorporate qualities such as health, socialisation and recreation within the urban realm.

In this way, urban restoration through green and blue infrastructure solutions contributes to ecological, social, and cultural health in various holistic and interconnected ways (Hes and du Plessis, 2014; Mang and Reed, 2012; Pedersen Zari and Hecht, 2020). It does this by safeguarding the ecological and biological aspects of our unique native flora and fauna, while still filling our urban landscapes with life and meaningful experiences. Human bodily motions and 
experiences are vital to reintegrating and reconnecting with our natural surroundings and with other individual beings. To know the inclusive outlook between us and nature and the differences of inclusive and separatist views seems highly important to gaining a successful urban restoration outcome that incorporates humans experiencing natural spaces in infinite ways; from simply affection to intimate spiritual connections with nature that imposes bodily experiences, and through discoveries and memories rather than just 'making' urban restoration.

\section{Conclusion}

Green infrastructure provides opportunities for urban design investigations at architectural and landscape scales that can explore strategies fully linked to individual and community health. This is particularly important in the face of increased urbanisation. As a concept, Gl encapsulates a complex multi-layered system which brings together natural and semi-natural elements. In the context of urban environments, it provides a wide range of ecosystem services, including mental health benefits and public health benefits.

An examination of two design projects demonstrates the transformative aspects of developing a multi-layered, multifunctional application of Gl that contribute to individual and community health. By analysing and experimenting through design-led research and considering green and blue infrastructure approaches at architectural and landscape architectural scales, a re-framing of these urban structures and landscapes can provide new perspectives for health and wellbeing in a way that contributes to improved social, cultural and environmental health. These case studies demonstrate the opportunities and advantages of $\mathrm{Gl}$ to offset some of the pressures from increased densification and urbanisation in Wellington, Aotearoa-New Zealand.

In conclusion, urban planners and decision-makers need to investigate how to move beyond generic approaches to 'greening'in the form of open space design, e.g. parks, rooftop gardens, green walls, greenways or restored natural areas, such as streams or rivers, and instead, envision an urban Gl strategy that incorporates individual and community health benefits through design details and design strategies. Part of the aim of this paper was to demonstrate the value of landscape in crafting new design solutions to green and blue infrastructure, but more importantly, to re-shape the mindset of governmental agencies and associated stakeholders. As more residents relocate to urban areas, this need becomes increasingly critical.

\section{References}

ALLEN III, W. L. 2012. Environmental reviews and case studies: Advancing green infrastructure at all scales: From landscape to site. In Environmental Practice, vol. 14, 2012, no. 1, pp. 17-25.

BARTHEL, S. - PARKER, J. - ERNSTSON, H. 2015. Food and green space in cities: A resilience lens on gardens and urban environmental movements. In Urban studies, vol. 52, 2015, no. 7, pp. 1321-1338.

BOLUND, P. - HUNHAMMAR, S. 1999. Ecosystem services in urban areas. In Ecological economics, vol. 29, 1999, no. 2, pp. 293-301.

BUIZER, M. - ELANDS, B. - VIERIKKO, K. 2016. Governing cities reflexively - The biocultural diversity concept as an alternative to ecosystem services. In Environmental Science \& Policy, 2016, 62, pp. 7-13.

CLARKSON, B. D. - KIRBY, C. L. 2016. Ecological restoration in urban environments in New Zealand. In Ecological management \& restoration, vol. 17, 2016, no. 3, pp. 180-190.

CHANSE, V. - MOHAMED, A. - WILSON, S. - DALEMARRE, L. LEISNHAM, P. T. - ROCKLER, A. - SHIRMOHAMMADI, A. - MONTAS, H. 2017. New approaches to facilitate learning from youth: Exploring the use of Photovoice in identifying local watershed issues. In The Journal of Environmental Education, vol. 48, 2017, no. 2, pp. 109-120.

COLLINS, D. 2005. Organisational change: sociological perspectives. London : Routledge, 2005.

COSTANZA, R. - MAGEAU, M. - NORTON, B. - PATTEN, B. C. 1998. Predictors of ecosystem health. In Ecosystem health, 1998, pp. 240-250.

DE GROOT, R. S. - WILSON, M. A. - BOUMANS, R. M. 2002. A typology for the classification, description and valuation of ecosystem functions, goods and services. In Ecological economics, vol. 41, 2002, no. 3, pp. 393-408.

DE VRIES, S. - TEN HAVE, M. - VAN DORSSELAER, S. - VAN WEZEP, M. - HERMANS, T. - DE GRAAF, R. 2016. Local availability of green and blue space and prevalence of common mental disorders in the Netherlands. In BJPsych Open, vol. 2, 2016, no. 6, pp. 366-372.

ELMQVIST, T. - FRAGKIAS, M. - GOODNESS, J. - GÜNERALP, B. MARCOTULLIO, P. J. - MCDONALD, R. I. - PARNELL, S. - SCHEWENIUS, M. - SETO, K. C. - WILKINSON, C. 2013. Urbanization, biodiversity and ecosystem services: challenges and opportunities: a global assessment. Cham : Springer Nature, 2013, 755 p

FOLKE, C. 2006. Resilience: The emergence of a perspective for social-ecological systems analyses. In Global environmental change, vol. 16, 2006, no. 3, pp. 253-267.

GALLOPÍN, G. C. 2006. Linkages between vulnerability, resilience, and adaptive capacity. In Global environmental change, vol. 16, 2006, no. 3, pp. 293-303.

GRELLIER, J. - WHITE, M. P. - ALBIN, M. - BELL, S. - ELLIOTT, L. R. GASCÓN, M. - GUALDI, S. - MANCINI, L. - NIEUWENHUIJSEN, M. J. SARIGIANNIS, D. A. - VAN DEN BOSCH, M. - WOLF, T. - WUIJTS, S. - FLEMING, L. 2017. Blue Health: a study programme protocol for mapping and quantifying the potential benefits to public health and wellbeing from Europe's blue spaces. In BMJ open, vol. 7, 2017, no. 6, e016188.

HAMPDEN-TURNER, C. - TROMPENAARS, F. 2011. Riding the waves of culture: Understanding diversity in global business. London : Hachette, 2011.

HARTIG, T. - MITCHELL, R. - DE VRIES, S. - FRUMKIN, H. 2014. Nature and health. In Annual review of public health, 2014, 35, pp. 207-228. HES, D. - DU PLESSIS, C. 2014. Designing for hope: pathways to regenerative sustainability. London : Routledge, 2014.

KAMIRYO, D. - SAKASHITA, K. - MATSUMOTO, Y. 2011. A New Publicness. Towards a New Cityscape, 2011, pp. 78-79.

KAPLAN, G. T. - ROGERS, L. J. 2003. Gene worship: Moving beyond the nature/nurture debate over genes, brain, and gender. New York: Other Press, 2003

KAPLAN, R. - KAPLAN, S. - RYAN, R. 1998. With people in mind: Design and management of everyday nature. Washington DC : Island press, 1998.

KIM, G. - COSEO, P. 2018. Urban park systems to support sustainability: the role of urban park systems in hot arid urban climates. In Forests, vol. 9, 2018, no. 7, pp. 439.

KIM, G. - MILLER, P. A. 2019. The impact of green infrastructure on human health and well-being: The example of the Huckleberry Trail and the Heritage Community Park and Natural Area in Blacksburg, Virginia. In Sustainable Cities and Society, 2019, 48, 101562. 
KIM, G. - MILLER, P. A. - NOWAK, D. J. 2015. Assessing urban vacant land ecosystem services: Urban vacant land as green infrastructure in the City of Roanoke, Virginia. In Urban Forestry \& Urban Greening, vol. 14, 2015, no. 3, pp, 519-526.

KUO, F. E. - BACAICOA, M. - SULLIVAN, W. C. 1998. Transforming inner-city landscapes: Trees, sense of safety, and preference. In Environment and behavior, vol. 30, 1998, no. 1, pp. 28-59.

KUO, M. 2015. How might contact with nature promote human health? Promising mechanisms and a possible central pathway. In Frontiers in psychology, 2015, 6, pp. 1093.

LEHMAN, J - NELSON, S. 2014. Experimental politics in the Anthropocene. In Progress in Human Geography, vol. 38, 2014, no. 3, pp. 444-447.

LOVETT, G. M. - JONES, C. G. - TURNER, M. G. -WEATHERS, K. C. 2005. Ecosystem function in heterogeneous landscapes. In Ecosystem function in heterogeneous landscapes, 2005, pp. 1-4.

LU, F. - LI, Z. 2003. A model of ecosystem health and its application. In Ecological Modelling, vol. 170, 2003, no. 1, pp. 55-59.

MANG, P. - REED, B. 2012. Designing from place: a regenerative framework and methodology. In Building Research \& Information, vol. 40, 2012, no. 1, pp. 23-38.

MARQUES, B. - McINTOSH, J. - CAMPAYS, P. 2018. Participatory design for under-represented communities: A collaborative designled research approach for place-making. In Handbook of research on civic engagement and social change in contemporary society. Hershey, PA : IGI Global, 2018, pp. 1-15.

MARQUES, B. - MCINTOSH, J. - HATTON, W. - SHANAHAN, D. 2019. Bicultural landscapes and ecological restoration in the compact city: The case of Zealandia as a sustainable ecosanctuary. In Journal of Landscape Architecture, vol. 14, 2019, no. 1, pp. 44-53.

MENZIES, D. - RENATA, A. - WHAANGA-SCHOLLUM, D. 2016 Connecting eco-systems and belief systems through regeneration and innovation. In X-section journal, vol. 6, 2016, no. 1, pp. 98-105. NIKOLOGIANNI, A. - MOORE, K. - LARKHAM, P. 2019. Making sustainable regional design strategies successful. In Sustainability, vol. 11, 2019, no. 4, pp. 1024.

NUTSFORD, D. - PEARSON, A. L. - KINGHAM, S. - REITSMA, F. 2016 Residential exposure to visible blue space (but not green space) associated with lower psychological distress in a capital city. In Health \& place, 2016, 39, pp. 70-78.

PEDERSEN ZARI, M. - HECHT, K. 2020. Biomimicry for regenerative built environments: Mapping design strategies for producing ecosystem services. Biomimetics, 5(2), 18.

RAPPORT, D. J. - COSTANZA, R. - MCMICHAEL, A. J. 1998. Assessing ecosystem health. In Trends in ecology \& evolution, vol. 13, 1998, no. 10, pp. 397-402.

RUDLIN, D. - FALK, N. 2009. Sustainable Urban Neighbourhood: Building the $21^{\text {st }}$ century home. Oxford : Butterworth-Heinemann, 2009.

SANDSTRÖM, U. G. 2002. Green infrastructure planning in urban Sweden. In Planning practice and research, vol. 17, 2002, no. 4 pp. 373-385.
SCHRIJNEN, P. M. 2000. Infrastructure networks and red-green patterns in city regions. In Landscape and Urban Planning, vol. 48, 2000, no. 3-4, pp. 191-204.

SELIGMAN, M. E. 2002. Positive psychology, positive prevention, and positive therapy. In Handbook of positive psychology, vol. 2, 2002, pp. 3-12.

TILMAN, D. - ISBELL, F. - COWLES, J. M. 2014. Biodiversity and ecosystem functioning. In Annual review of ecology, evolution and systematics, 2014, 45, pp. 471-493.

TÓTH, A. - HALAJOVÁ, D. - HALAJ, P. 2015. Green infrastructure: a strategic tool for climate change mitigation in urban environments. In Ecology \& Safety, 2015, 9, pp. 132-138.

TZOULAS, K. - KORPELA, K. - VENN, S. - YLI-PELKONEN, V. KAŹMIERCZAK, A. - NIEMELA, J. - JAMES, P. 2007. Promoting ecosystem and human health in urban areas using Green Infrastructure: A literature review. In Landscape and urban planning, vol. 81, 2007, no. 3, pp. 167-178.

UNITED NATIONS. 2018. World Urbanization Prospectus. The 2018 Revision. UN. Retrieved September 2, 2020, from https://www. un.org/development/desa/en/news/population/2018-revision-ofworld-urbanization-prospects.html

VAN DER RYN, S. - COWAN, S. 2013. Ecological design. Washington DC : Island press, 2013.

VIERIKKO, K. - ELANDS, B. - NIEMELÄ, J. - ANDERSSON, E. - BUIJS, A. - FISCHER, L. K. - HAASE, D. - KABISCH, N. - KOWARIK, I. - LUZ, A. C. - STAHL, A. O. - SZARAZ, L. - VAN DER JAGT, A. - VAN DEN BOSCH, C. K. 2016. Considering the ways biocultural diversity helps enforce the urban green infrastructure in times of urban transformation. In Current opinion in environmental sustainability, 2016, 22, pp. 7-12.

VOELKER, S. - KISTEMANN, T. 2013. Reprint of: "I'm always entirely happy when I'm here!" Urban blue enhancing human health and well-being in Cologne and Düsseldorf, Germany. In Social Science \& Medicine, 2013, 91, pp. 141-152.

WALMSLEY, A. 2006. Greenways: multiplying and diversifying in the $21^{\text {st }}$ century. In Landscape and urban planning, vol. 76, 2006, no. 1-4, pp. 252-290.

WELLINGTON CITY COUNCIL. 2020. Summary of Our City Tomorrow : Draft Spatial Plan for Wellington City. WCC. Retrieved September 10, 2020 from https://planningforgrowth.wellington. govt.nz/ data/assets/pdf file/0012/13611/J010892-Spatial-Plan2020-Summary-Draft-V9-Web.pdf

WHEELER, B. W. - WHITE, M. - STAHL-TIMMINS, W. - DEPLEDGE, M. H. 2012. Does living by the coast improve health and wellbeing? In Health \& place, vol. 18, 2012, no. 5, pp. 1198-1201. 